\title{
Mobile-Learning Development For Supporting Scientific Approaches in Chemical Learning Using Flipped Classroom Strategy
}

\author{
I Made Tegeh ${ }^{1 *}$, Ida Bagus Nyoman Sundria², I Komang Sudarma3 ${ }^{3}$ I Gde Wawan \\ Sudatha ${ }^{4}$
}

1,2,3,4 Department of Technological Education, Ganesha University of Education

\section{A R T I C L E I N F O \\ Article history: \\ Received 25 February 2020 \\ Received in revised \\ Form 29 March 2020 \\ Accepted 20 April 2020 \\ Available online 29 May 2020}

Keyword:

mobile learning, scientific approach, flipped classroom

\begin{abstract}
A B S T R A K
This study aims to describe the characteristics of M-learning that are effective in supporting flipped classroom in high school chemistry learning using the scientific approach and describe the feasibility of M-learning developed in terms of content validity, pedagogy, media and technology, and readability by the user. This research is focused on making an M-learning prototype on the chemistry topic of class $\mathrm{X}$ high school. The M-learning prototype was developed using the Luther model and its formative evaluation adapted the formative evaluation of Dick \& Carey. Data were collected by questionnaire method and analyzed by descriptive qualitative and quantitative descriptive analysis techniques. The output of this research is the study of indicators and the scope of material for 6 chemistry topics in high school class X and Mlearning prototypes for one chemical topic that has fulfilled the feasibility of content, pedagogy, media design, technical and individual trials. M-learning can be accessed by users who can be positioned as teachers or students. The results showed that: the characteristics of M-learning were presenting ionic and covalent bonding material, the strategies used were felipped classroom,
\end{abstract} learning directed to follow the steps of the scientific approach starting from observing, asking, gathering information, associating, and communicating, and each M-learning meeting contains material, videos, student worksheets, and chats, M-learning products according to content experts are quite good with a value of 72.31, learning media experts and learning design experts give their respective scores 96,92 and 95.00 with very good criteria, chemistry subject teachers give a value to M-learning products of 96 and have very good criteria, and individual trials of three low, medium, and high students show good results with average score of 82.86. It can be concluded that M-Learning with a flipped classroom strategy can support scientific approaches in chemical learning.

\section{Introduction}

Constructivist view has long been echoed and used as a jargon of learning innovation, but in reality the realization of this view has not fundamentally changed three important aspects of learning, namely goals, processes and evaluations. Entering the century of learning, along with the advancement of information and communication technology, changes in the order of life take place so rapidly that the future becomes unpredictable. This situation requires someone to be able to continue to learn and adapt to complex and diverse situations. Degeng (2016) suggests that entering the age of learning (information age), learning is no longer seen as an effort to prepare for the future, but a process so that someone can live anytime, anywhere, and in any situation. Learning that emphasizes content mastery (uniformity) is no longer relevant. Learning must shift towards preparing someone to be able to learn (learning how to learn).

The encouragement of the curriculum so that learning using the scientific approach is a national awareness that emphasis on learning must be shifted to the process or way of learning. Emphasis on the process is believed to produce superior human resources that can live in various situations. Superior resources are resources that have 21st century skills, including critical thinking, creative thinking, problem solving skills, decision-making abilities, collaboration skills, communication skills, information 
literacy, media, and technology (Roblyer \& Doering, 2013). Learning objectives must be shifted towards achieving goals to produce superior resources above.

Although the curriculum has long encouraged student learning centered using a scientific approach (KTSP and K13), the implementation of this approach in the field has not yet been realized. The survey conducted by Kirna, et al. (2015) showed that only $55.2 \%$ of teachers (from 26 chemistry teachers in Bali) stated that they implemented a scientific approach with a range of $5 \%$ to $90 \%$ of chemical topics in high school. That is, among these teachers, there are teachers who are very rare and some who are quite intensive in implementing this approach. The deepening results of these facts show that the actual implementation of learning is not in accordance with the scientific approach. In contrast to the findings of Kirna (2007) who argued that the main obstacle of teachers was the lack of facilities/infrastructure, the Kirna survey (2015) found that the main constraints raised by teachers were no longer facilities / infrastructure, but (1) lack of student motivation and inquiry abilities. this approach does not work, (2) long time is needed while the available time is limited, (3) lack of learning resources that support the scientific approach, (4) practicum requires a large amount of energy, while the effect on student mastery is not worth the effort needed, and (5) the ability of teachers to lack in developing supporting learning resources. Findings of Kirna et al. supports that suggested by Sanjaya (2009) that besides technical constraints, there are also cultural constraints, namely teachers are not accustomed to managing learning using a scientific approach and have confidence that this approach is not effective. This is what causes the curriculum to be only "dashing on paper", but its implementation always falls on learning that is teacher centered which preserves receptive learning culture.

Expectations to develop superior, character and capable of competing human resources cause the receptive learning culture of students to be shifted to an active and productive learning culture and foster a spirit of lifelong learning. The main constraints experienced by teachers must be found solutions in applying scientific approaches, such as lack of supporting learning resources, limited time, and low student motivation. In this connection, two essential things that are done are (1) creating an environment / learning resource that stimulates learning, and (2) innovating learning strategies using an efficient scientific approach and can motivate student learning.

The progress of ICT today is very potential to develop a learning environment that facilitates student learning centered using a scientific approach. The progress of ICT has made it easier to develop rich learning resources and learning tasks. The progress of ICT has entered the 4th era (Roblyer \& Doering, 2013), an era of mobile technology, social media, and open source characterized by ease and speed in internet access. This era makes e-learning increasingly powerful to use in learning. This mobile era has directed personalize learning because someone has been able to access his own information (bring your own device, BYOD). All the advantages of computers can be transferred to mobile technology so that the creation of a mobile-based learning environment is very prospective because ownership of mobile technology has been very widespread, from children to the elderly.

The journey of utilizing ICT technology in learning does not necessarily prove its promising superiority. No matter how sophisticated technology, technology is not a magic wand that can easily solve problems. Technology does not by itself (stand alone) provide its effectiveness in learning. The effectiveness of technology depends on how the technology is integrated or utilized in learning (Roblyer, 2013). Capital wealth information format in an e-learning and also various features of learning activities is not enough to make ICT superior in learning.

Some research findings report that ICT utilization provides inconsistent results (Passerini, 2007). These inconsistent results are partly due to (1) the low quality of ICT-based learning resources used and (2) the inaccuracy of the integration strategy in learning. Leacock and Nesbit (2007) found that most of the quality of online learning environments is low, content quality standards are low and have not been designed according to the characteristics of the subject and pedagogy. Barger \& Byrd (2011) suggest that the most important thing in determining the success of online learning is the availability of the right online learning environment.

The second important factor that determines the effectiveness of ICT utilization is the strategy of integration in learning. Recent research findings indicate that Blended Learning (BL), a learning delivery strategy that combines the advantages of online and face-to-face learning, is very prospective to improve the quality of the learning process (Demirci, 2010; Kim \& Bateman, 2010; Shroff, \& Deneen, 2011 ; Rosenthal \& Weitz, 2012; Florida, 2012). The research findings (Kirna et al., 2015) also showed the effectiveness of the use of BL in high school chemistry learning seen from the improvement in learning outcomes, even though students' online activities were not optimal. The results of student responses indicate that the motivation of high school students in Bali learns to use high ICT and learning using a scientific approach delivered in a manner that encourages and facilitates their learning. Some of the 
obstacles that have caused optimal online activity are (1) the problem of laptop ownership (students have an android mobile phone, but not all students have a laptop), (2) important materials such as flash animation / simulation can only be accessed with a laptop, cannot accessed using mobile phones, (3) discussions in online forums are less desirable because students prefer social media to discussion.

One of the blended learning strategies that is currently being the focus of research is flipped classroom (reverse class) (Garza, 2014). Flipped class is a BL strategy where students learn independently through video tutorials and / or other information and work on online learning tasks, while in class face to face students discuss the task and discuss new assignments. The results of research on flipped class room show that this strategy is effective (Bishop \& Verleger, 2013). The results of the Garza review (2014) show that flipped classroom is superior in time efficiency and encourages active learning and deep learning (Danker, 2015). Therefore, the application of this strategy has the potential to solve the less optimal problem of applying the scientific approach in national education. A number of piloting programs have been carried out by applying flipped class in educational institutions (Danker, 2015). Like elearning, the effectiveness of flipped classroom is determined by the quality of the online learning environment used.

The success of online learning also requires students who are self-directed, self-regulated, selfdeciplined, confortable with written communication, have the character of information sharing, and have technical technology skills (Dabbagh \& Ritland, 2005). Unfortunately, except for technological technical skills, the above abilities are not shared by students. The above abilities must be built into national education. Shifting receptive learning patterns into actively productive ways to develop 21st century skills must change learning strategies. The application of BL, such as flipped classroom supported by the right learning environment is a solution that cannot be avoided. The right learning environment is a learning environment that gives students the freedom to learn and control / regulate their own learning. The learning environment is not enough to only facilitate learning (to facilitate learning), but encourages learning to occur, even fosters learning (Degeng, 2016). Here, the learning environment based on mobile learning is the right choice.

\section{Methods}

M-learning development adapts the Luther Model (1994) which consists of the concepts, design, collecting materials, assembly, testing, and distribution stages. The testing phase, namely beta testing adapts the formative test of Dick, Carey, \& Carey (2001).

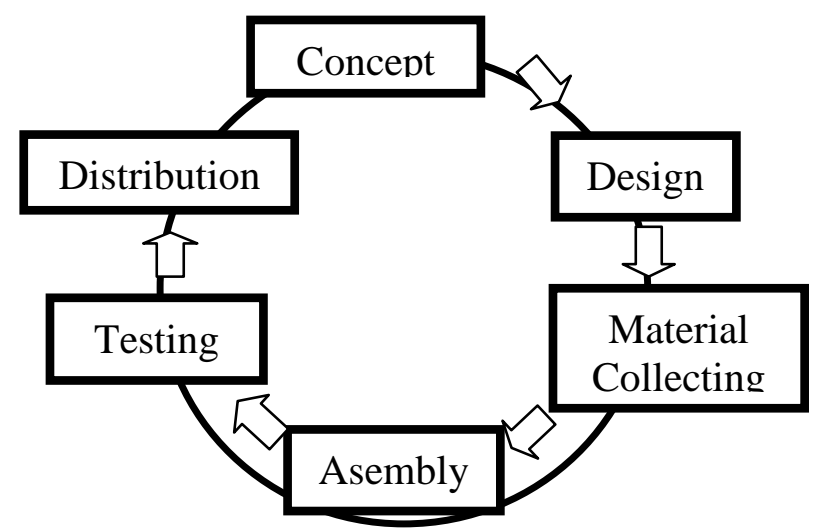

Picture1. Luther Model Step

Based on Figure 1 it is known that the development of M-Learning with the Luther Model consists of six steps. Luther Model consist of six steps: concept, design, material collecting, assembly, testing, distribution. The first stage is concept. At this stage, the result is a curriculum analysis (content standards, process and evaluation), a team of FGD with chemistry teachers reviewing online content (Kirna, et al, 2016) to establish indicators, material coverage, and learning context, as well as macro and micro pedagogy.

In the second stage, what the researcher does is the design stage. The result is making a program map (program mapping), making a video tutorial scenario, making an M-mobile flow chart to fit the Flipped classroom. In the third stage, the Luther Model is material collecting. This stage is done to make learning objects in accordance with those already designed in the mapping program, such as video tutorials, animations / simulations, text material, and images. 
The fourth step is assembly. This stage is carried out to arrange all learning objects according to the M-learning structure. The fifth stage is testing. At the Testing stage, formative tests are carried out in the form of (1) content expert and pedagogical evaluations, media, and practitioners as well as (2) individual trials. The sixth distribution step in the first year has not yet been implemented because the product development only reached a prototype that needed more extensive testing.

In this study, the qualitative data obtained were analyzed until the study was used as a reference to make M-learning protoypes on one class X high school chemistry topic. Qualitative and quantitative data from the results of evaluations / expert input and users (practitioners / teachers and individual student tests) analyzed descriptively to look at the feasibility of content, pedagogy, media and technical design, and the level of practicality (practicality) of online content as well as material for improving the $\mathrm{M}$ learning prototype.

\section{Result and Discussion}

\section{Product Description of Teaching Materials}

Based on the steps in developing the Luther Model, the first step is the concept step. In this step, an analysis of Curriculum 2013 was conducted on Chemistry Class X High School subjects. The analysis activity was carried out through Focus Group Discussion (FGD) researchers, chemists, and high school chemistry teachers in class X. The chemist invited to the FGD was a lecturer in the Department of Chemistry, Faculty of Mathematics and Natural Sciences, Universitas Pendidikan Ganesha on behalf of Dr. Siti Maryam, M.Pd. and Dr. I Dewa Ketut Sastrawidana, S.Si., M.Sc. Chemistry subject teachers invited in the FGD are (1) two teachers of SMAN 1 Singaraja on behalf of Kadek Ratna Widiastuti, S.Pd. and Ida Ayu Putu Widiartini, M.Pd. and (2) two teachers of SMAN 2 Singaraja in the name of Ni Made Parseni, S.Pd. and Drs. I Made Arya Kertawan, M.Pd.

The initial plan for the proposed study was targeted at setting indicators, material coverage, and learning contexts, as well as macro and micro pedagogues for six topics in high school Chemistry class $\mathrm{X}$ subjects. In the implementation of the FGD it was agreed to review all topics of the Class X High School Chemistry subjects. Thus, from the target of six topics the assessment of indicators and material changed to nine topics. The nine topics are (1) the nature of chemistry and the scientific method, (2) development of atomic models and atomic structures before modern atoms, (3) atomic structure of quantum mechanics, (4) elemental peroidic systems, (5) ionic and covalent bonds, (6) molecular forms, (7) polarity, (8) metal bonds, and (9) forces between molecules.

The results of the analysis of indicators and Chemistry subject matter in class X SMA in semester I were conducted in stages, namely (1) the division of Chemistry subject units in class X SMA in the first semester, (2) examples of material analysis, and (3) analysis of the indicators and learning activities On each topic of knowledge that is built includes four main things, namely factual, concepts, principles / theory / law / model, and procedural. Some input from high school teachers in FGD activities is presented in Table 1.

Table 1. Teacher'Comment about Indicator and Content

\begin{tabular}{cll}
\hline No. & Teacher & \multicolumn{1}{c}{ Comment } \\
\hline 1 & A & The Born Haber cycle, just introduced because it requires a lot of time \\
\cline { 3 - 3 } & B & $\begin{array}{l}\text { Wabridization Theory, only simple examples are introduced. } \\
\text { semester II) }\end{array}$ \\
\hline 3 & A \& C & $\begin{array}{l}\text { Principles / Theories / Laws / Models: plus (1) Modern Atomic Models and (2) } \\
\text { Orbital }\end{array}$ \\
\hline 4 & C & $\begin{array}{l}\text { On the concept added: Ionization reactions in the formation of ion charges } \\
\text { In the Procedure added: How to write the process of forming ion bonds and chemical } \\
\text { formulas of compounds }\end{array}$ \\
\hline 5 & D & Principle: plus full and half rules \\
\cline { 3 - 3 } & & Procedure: plus How to determine elemental periodicity \\
\hline
\end{tabular}

In the analysis and study with the research team, it was decided to make one topic in the first semester Chemistry class $\mathrm{X}$ as the topic at M-Learning. The topic decided to be M-Learning is ion and covalent bonds. Thus, the first characteristic of M-learning is presenting ionic and covalent bonding material. 
Learning through M-learning includes two meetings. Each meeting contains videos about material content, Student Worksheets (LKS), and space for chatting or communicating with each other between teachers and students as well as students and students. Videos and worksheets can be accessed through smart media mobile phones, so that wherever and whenever students can learn according to their wishes. Learning with this system requires students to learn actively and independently. They watch videos, read material, work on worksheets outside class meetings. During class meetings students and teachers discuss the things that have been learned and the tasks that have been done and the tasks ahead. This strategy is very in line with the nature of Curriculum 2013 which emphasizes student-centered learning. Students must actively learn and organize themselves to use the time to study independently.

There are some effect of using flipped classroom strategy on the academic achievement. Elian \& Hamaidi (2018) show that there are statistically significant differences in the Mean on the academic achievement test attributed to the teaching strategy, in terms of the members of experimental group. Elementary and secondary teacher feel positive about the use and the importance of mobile technology in the classroom (Jong \& Anderson, 2018). Chung \& Lee (2018) show that the flipped learning approach and results of the analysis conducted found that flipped learning improve learning motivation and attitudes. Anohah, Oyeler, \& Suhonen (2017) based on metanalysis research show that the author's study reveals that mobile learning in computing education has the potential to increase several affective traits of learners.

\section{Validation Analysis of M-Learning Product}

The feasibility of M-learning is seen from the validity of the content experts, learning media expert, and the learning design expert carried out through expert test activities or expert judgment. Content experts giving a total score of 47. Learning media expert giving a total score 63 and the learning design expert giving a total score of 63.

\section{Advantages}

The development of M-Learning carried out using the Luther Model. In the concept step, the results are found in curriculum analysis (content standards, process and evaluation), FGD teams with chemistry teachers review online content (Kirna, et al, 2016) to establish indicators, scope of material, and learning context, as well as macro pedagogy and micro. In the design steps are making program mapping, making video tutorial scenarios, making M-mobile flowcharts to fit the Flipped class. The third step of the Luther Model is gathering material. These steps are carried out to make learning objects according to what has been designed in the mapping program, such as video tutorials, animations / simulations, text materials, and images. In the initial steps carried out to arrange all learning objects in accordance with the structure of M-Learning. At the Testing stage, formative tests are carried out in the form of (1) content expert and pedagogical evaluations, media, and practitioners as well as (2) individual trials. The distribution phase in the first year was not yet implemented because product development only reached prototypes that needed more extensive testing. The advantages of M-Learning are learning through Mlearning includes two meetings. Each meeting contains videos about material content, Student Worksheets (LKS), and space for chatting or communicating with each other between teachers and students as well as students and students. Videos and worksheets can be accessed through smart media mobile phones, so that wherever and whenever students can learn according to their wishes. Learning with this system requires students to learn actively and independently. They watch videos, read material, work on worksheets outside class meetings. During class meetings students and teachers discuss the things that have been learned and the tasks that have been done and the tasks ahead. This strategy is very in line with the nature of Curriculum 2013 which emphasizes student-centered learning. Students must actively learn and organize themselves to use the time to study independently.

\section{Teachers' Response Analysis}

Evaluation of the teacher responses to the M-Learning product is done by giving a questionnaire to assess the M-Learning. Based on the recapitulation of the results of the analysis of teacher responses to the teaching of M-Learning, the total score given by the teacher to the M-learning product is 48 , so the value given is 96 . This means that the M-learning product is in very good criteria. Qualitatively the teacher gives some comments and suggestions for improving the M-learning product.

\section{Student's Responses Analysis}

Evaluation of student responses to M-Learning products is done by giving questionnaires to assess the M-Learning. Student response data obtained through M-Learning trials to three students. Based on data analysis from the data that has been done, it is known that the first, second, and third students 
give an assessment with each total score of 60,59 , and 55 . Thus the value given by students is 85.71 ; 84.29; and 78.57. The mean assessment of M-learning products by students was 82.86 . This means that $M-$ learning products based on the assessment of students are in good criteria

\section{Discussion}

Based on the results of the validation analysis by the content expert, the contents contained are appropriate. The subject matter expert gave a score of 72.31. This value is converted to a five-scale Benchmark Reference (PAP). Based on the conversion results it is known that the value or level of achievement of M-learning of 72.31 is at the level of achievement of $65 \%-74$. This means that M-learning products according to content experts have good criteria. Furthermore, based on inputs qualitatively carried out revisions to the M-learning product. Revisions made to M-learning products include the addition of Competency Standards, Basic Competencies, and learning objectives. Material that is too long to be edited again to make it simpler. Covalent bonding material and examples are developed further, so that they are more easily understood by students. Finally, the revision in accordance with the content expert input is to look at the sentences on the student worksheet to make it more connected and meaningful.

Based on the results of the analysis, learning media experts gave a value of M-learning products of 96.92. When converted to the five-benchmark Benchmark Assessment Criteria, the value is in the range of 90-100. This means that M-learning products have very good criteria.

The results of the data analysis of the learning design expert questionnaire sheet, the assessment given by the learning design expert is 95 . This means that the M-learning product seen from the learning design has very good criteria because the value is in the range of values 90-100. Learning design experts do not provide advice or input, but provide comments that M-learning is very good and supports students to learn actively and independently.

Then based on the results of teacher's assessment analysis, it was concluded that the worksheets in the form of video shows to distinguish the properties of ionic and molecular compounds are easily understood, especially regarding the electrical conductivity properties between $\mathrm{FeCl} 3$ and paraffin.

Based on the results of the assessment by the first student, it was concluded that learning by using mobile learning is very fun, but the concept used must be even more interesting so that students are more interested in learning. Based on the results of the second student assessment, it was concluded that from mobile learning I can remember and master the subject matter well and based on the assessment of the third student it is concluded that mobile learning that contains this video media can easily understand the material presented, easy to remember the material taught by my teacher at school

In general, it can be seen that the results of the assessment both from the experts and the results of the trial to a teacher and three students of class X SMAN 2 Singaraja have met the indicators of success in either category. Based on these results it can be said that the development of innovative teaching materials such as the development of M-Learning can support a scientific approach in chemistry learning using a flashed classroom strategy.

Assessment of M-Learning acceptance can be seen from the results of the questionnaire analysis of teacher and student responses. The total score given by the teacher to the M-learning product is 48 , so the score given is 96 . This means that the M-learning product is in very good criteria. Student responses to MLearning can be seen from the results of the questionnaire analysis. The first, second, and third students gave an assessment with a total score of 60,59 , and 55 respectively. Thus the scores given by the students were 85.71; 84.29; and 78.57. The mean assessment of M-learning products by students was 82.86 . This means that M-learning products based on the assessment of students are in good criteria. From the results of the average score of student and teacher responses to M-Learning are in the good and very good categories so it can be concluded that M-Learning can be well received by teachers and students. From the description above, it can be clearly seen that the development of M-Learning can support a scientific approach to learning chemistry using a flashed classroom strategy.

The discussion above implies that the development of M-Learning with a flipped classroom strategy has good qualifications. This is in line with research (Angglin, et al., 2004); Tversky, 2005); Kirna, 2004; Kirna, 2007, Falvo, 2008) who found that the use of visualization (multimedia) in science science learning, especially chemistry, excels in improving learning outcomes. Other research by (Turkmen, 2007; So Kong, 2008; Kirna, 2009; Kirna 2010; Wijaya, Kirna, Suardana, 2012) namely the use of ICT / multimedia offline is also effective to support inquiry-based learning. Research conducted (Florida 2012; Rosenthal \& Weitz, 2012; Kirna, 2013; Kirna, 2014) found that blended learning (BL), which is a combination of online learning and face-to-face learning was reported to be effective. Kirna, et al (2015) develop online content for high school chemistry learning to support the scientific approach delivered in BL. Online content is 
developed by considering the characteristics of chemical studies that synchronize macroscopic studies, sub-microscopy, and symbols so that visualization becomes an important component in online content. Online content also contains learning activities (LKS) to facilitate student inquiry and contains online discussion and self-evaluation facilities. Kirna, et al. 2015 showed that the online content design developed was a good reference in developing an online learning environment to support a scientific approach. Thus, it was found that the development of M-Learning with a flipped classroom strategy could support scientific approaches in learning chemistry.

\section{Conclusion}

Development of M-Learning produces products that have good qualifications. This M-Learning acceptance assessment can be seen from the results of the teacher questionnaire analysis and student responses to the M-Learning trial. The total score given by the teacher to the M-learning product is 48 , so the value given is 96. The student's response to the M- Learning can be seen from the results of the questionnaire analysis. The first, second, and third students gave an assessment with a total score of 60 , 59 , and 55 respectively. Thus the scores given by the students were $85.71 ; 84.29$; and 78.57. The mean assessment of M-learning products by students was 82.86 . So it can be concluded that M-Learning can be well received by teachers and students. Most importantly, the development of M-Learning with a flipped classroom strategy can support scientific approaches in chemical learning.

\section{References}

Anglin, G. J., Vaez, H. \& Cunningham, K. L. 2004. Visual Representations and Learning: The Role of Static and Animated Graphics. Dalam David H. Jonassen (Ed.). Handbook of Research on Educational Communications and Technology (hlm. 865-916). Mahwah: Lawrence Erlbaum Associates.

Anohah, E., Oyelere, S. S., \& Suhonen, J. 2017. Trends of mobile learning in computing education from 2006 to 2014: A systemic review of research publications. International Journal of Mobile and Blended Learning, 9(1): 16-19.

Baser, M. 2006. Promoting Conceptual Change through Active Learning Using Open Source Software for Physics Simulations. Australasian Journal of Educational Technology, 22(3): 336-354.

Bishop, J. L., \& Verleger, M. A. 2013 The Flipped Classroom: A Survey of Research. $120^{\text {th }}$ Annual Conference \& Exposition, June 23-26: Atlanta.

Chung, E.J \& Lee, B.H. 2018.The effects of flipped learning on learning motivation and attitudes in a class of college physical theraphy students. Journal of Problem-Based Learning, 5(1): 29-36.

Danker, B. 2015. Using Flipped Classroom Approach to Explore Deep Learning in Large Classroos. The IAFOR Journal of Education, 3(1): 171-186.

Dasna, I.W. 2005. Kajian Implementasi Model Siklus Belajar (Learning Cycle) dalam Pembelajaran Kimia. Makalah Seminar Nasional MIPA dan Pembelajarannya, FMIPA UM - Dirjen Dikti Depdiknas, 5 September 2005 .

Degeng, I N.S. 2016. Revolusi Mental Pendidikan Guru untuk Memperbaiki Kualitas Pembelajaran. Procceding KONASPI 8. Diselenggarakan pada 12-15 Oktober 2016: Jakarta.

Dick, W., Carey, L., \& Carey, J.0.2001 The Systematic Design of Instruction (Fifth Ed).New York: Longman.

Elian, S. A. \& Hamaidi, D.A. 2018. The effect of using flipped classroom strategy on the academic achievement of fourth grade students in Jordan. iJET, 13(2): 110-125.

Florida, J. (2012). Analogy-Integrated e-Learning Module: Facilitating Students' Conceptual Understanding. Journal of Computers in Mathematics and Science Teaching, 31(2), 139-157.

Falvo, D. 2008. Animations and Simulations for Teaching and Learning Molecular Chemistry. International Journal of Technology in Teaching and Learning, 4(1): 68-77. 
Garza, A. S. 2014.The Flipped Classroom Teaching Model and It's Use for Information Literacy Instruction. Communication in Information Literacy, 8(1):7-22.

Given, B.K. 2002. Teaching to The Brain's Natural Learning System. Alexandria:ASCD

Jong, D.D., Grundmeyer, T., \& Anderson, C. 2018. Comparative study of elementary and secondary teacher perceptions of mobile technology in classrooms. International Journal of Mobile \& Blended Learning, 10(1): 12-15.

Kalyuga, S. 2007. Enhancing Instructional Efficiency of Interactive E-learning Environments: A Cognitive Load Perspective. Educ Psychol Rev, 19:387-399.

Luther, A.C. 1994. Authoring Interactive Multimedia. Boston: AP Professional.

Kirna. I M. 2004. Penerapan Strategi Realita-Analogi-Diskusi Menggunakan Multimedia Untuk meningkatkan Kualitas Pemahaman Siswa SMA Kelas I Semester I tentang Materi dan Perubahan Materi. Laporan Penelitian. Singaraja: STKIP Singaraja.

Kirna, I M., Sukerti, M. \& Suardana, N. 2007. Pengembangan Model Pembelajaran Sains yang Berorientasi Konteks dan Struktur (Contextuals and Structure Oriented Learning) pada Kompetensi Dasar Kimia di SMP. Laporan Penelitian Hibah Bersaing, Singaraja: Undiksha.

Kirna, I M. 2009. Pengembangan Pemahaman Konseptual Kimia pada Pebelajar Pemula dengan Model Sinkronisasi Makroskopis dan Sub-mikroskopis Berbantuan Multimedia Interaktif, Laporan Penelitian Fundamental. Singaraja: Undiksha

Kirna, I M. 2010. Integrasi Hypermedia dalam Strategi Siklus Belajar Untuk Meningkatkan Pemahaman Konsep Kimia Siswa SMP yang Memiliki Dua Gaya Belajar Berbeda. Laporan Hibah Doktor. Malang: PPS UM.

Kirna, I M. 2012. IbM Kelompok Guru Kimia SMAN 1 Sukasada dan SMAN 2 Busungbiu. Laporan P2M : UNDIKSHA.

Kirna, I M. 2012b. Pemanfaatan Multimedia Dalam Pembelajaran Menggunakan Model Siklus Belajar Pada Topik Asam-Basa. Proseding Seminar FMIPA II di UNDIKSHA, 30 Nopember 2012.

Kirna, I M. 2013. Penerapan Strategi Problem Posing yang disampaikan secara Blended Learning pada Perkuliahan Chemical Bonding. Proseding Seminar Nasional FMIPA III di UNDIKSHA, 30 Nopember 2013.

Kirna, I M., \& Mahadewi, N.L.P.P. 2014. Pengembangan Konten Online untuk Mendukung Blended Learning pada Perkuliahan Kimia Kuantum Dasar. Laporan Penelitian HB Desentraisasi. Singaraja: UNDIKSHA.

Kirna, I M., Sudria, I B.N., Tegeh, I M. 2015. Konten Online untuk Peningkatan Pemerataan Kualitas Proses dan Hasil Belajar Kimia SMA, Laporan Penelitian STRANAS Tahun I, Singaraja, UNDIKSHA.

Leacock, T. L. \& Nesbit, J. C. 2007. A Framework for Evaluating the Quality of Multimedia Learning Resources. Educational Technology \& Society, 10 (2): 44-59.

Lawson, A.E. 1995. Science Teaching and the Development of Thinking. California: Wadsworth Publishing Company.

Maxcy, S. J. 2003. Pragmatic Threads in Mixed Methods Research in the Social Sciences: The Search for Multiple Mode of Inquiry and the End of the Phylosophy of Formalism. Dalam A. Tashakkori \& C. Teddlie (Eds.). HandBook of Mixed Methods in Social \& Behavioral Research (hlm. 51-89). London : SAGE Publications. 
Passerini, K. 2007. Performance and Behavioral Outcomes in Technology-Supported Learning: The Role of Interactive Multimedia. Journal of Educational Multimedia and Hypermedia, 16(2):183-210.

Roblyer, M. D. 2013. Integrating Educational Technology into Teaching (sixth Ed.) Upper Boston, MA: Pearson.

Rosenthal, D. \& Weitz, R. (2012). Large-Course Redesign via Blended Learning: A Post-Implementation Assessment Across Institutions. International Journal on E-Learning, 11(2), 189-207.

Smaldino, S. E., Russell, J. D., Heinich, R. \& Molenda, M. 2005. Instructional Technology and Media for learning ( $8^{\text {th }}$ Ed.). Upper Saddle River: Pearson Education, Inc.

Stieff, M. 2005. Connected Chemistry: A Novel Modeling Environment for the Chemistry Classroom, (Online), 82(3), (http://www.JCE.DivCHED.org, diakses 22 April 2007).

Turkmen, H. 2006. What Technology Plays Supporting Role in Learning Cycle Approach for Science Education. The Turkish Online Journal of Educational Technology-TOJET, (Online), 5(2): 13036521, (http://www.eric.ed.gov/ ERICWebPortal/recordDetail?accno, diakses 20 Agustus 2008).

Tversky, B. 2005. Prolegomenon to Scientifict Visualization. Dalam J. K. Gilbert (Ed.). Visualization in Science Education (hlm. 29-42). Dordrecht: Springer.

Wu, H.K., Krajcik, J. S. \& Soloway, E. 2001. Promoting Understanding of Chemical Representations: Students' Use of a Visualization Tool in the Classroom. Journal of Research in Science Teaching, 38(7): 821-842.

Zumbach, J. 2006. Cognitive Overhead in Hypertext Learning Reexamined: Overcoming the Myths. Journal of Educational Multimedia and Hypermedia, 15(4): 411-433. 